This is an electronic reprint of the original article. This reprint may differ from the original in pagination and typographic detail.

\author{
Author(s): Ahtiainen, Juha; Hulmi, Juha; Lehti, Maarit; Kraemer, William J.; Nyman, Kai; Selänne, \\ Harri; Alen, Markku; Komulainen, Jyrki; Kovanen, Vuokko; Mero, Antti; Philippou, \\ Anastassios; Laakkonen, Eija; Häkkinen, Keijo
}

Title: $\quad$ Effects of resistance training on expression of IGF-I splice variants in younger and older men

Year: $\quad 2016$

Version:

Please cite the original version:

Ahtiainen, J., Hulmi, J., Lehti, M., Kraemer, W. J., Nyman, K., Selänne, H., Alen, M., Komulainen, J., Kovanen, V., Mero, A., Philippou, A., Laakkonen, E., \& Häkkinen, K. (2016). Effects of resistance training on expression of IGF-I splice variants in younger and older men. European Journal of Sport Science, 16(8), 1055-1063.

https://doi.org/10.1080/17461391.2016.1185164

All material supplied via JYX is protected by copyright and other intellectual property rights, and duplication or sale of all or part of any of the repository collections is not permitted, except that material may be duplicated by you for your research use or educational purposes in electronic or print form. You must obtain permission for any other use. Electronic or print copies may not be offered, whether for sale or otherwise to anyone who is not an authorised user. 


\title{
EFFECTS OF RESISTANCE TRAINING ON EXPRESSION OF IGF-I SPLICE VARIANTS IN YOUNGER AND OLDER MEN
}

\author{
Juha P. Ahtiainen ${ }^{a^{*}}$, Juha J. Hulmia, Maarit Lehti ${ }^{\mathrm{b}}$, William J. Kraemer ${ }^{\mathrm{c}}$, Kai Nyman ${ }^{\mathrm{d}}$, Harri \\ Selänne $^{\text {b }}$, Markku Alen ${ }^{\mathrm{e}}$, Jyrki Komulainen ${ }^{\mathrm{b}}$, Vuokko Kovanen ${ }^{\mathrm{f}}$, Antti A. Mero ${ }^{\mathrm{a}}$, Anastassios \\ Philippou $^{\text {g, Eija Pöllänen }}{ }^{\text {, Keijo Häkkinen }}{ }^{a}$
}

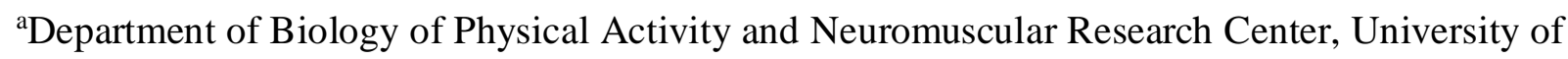
Jyväskylä, Jyväskylä, Finland

${ }^{\mathrm{b}}$ LIKES Research Center for Sport and Health Sciences, Jyväskylä, Finland

${ }^{\mathrm{c}}$ The Department of Human Sciences, The Ohio State University, USA

dJyväskylä Central Hospital, Jyväskylä, Finland

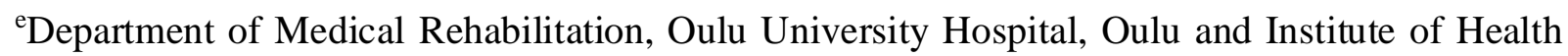
Sciences, University of Oulu, Oulu, Finland

fDepartment of Health Sciences and Gerontology Research Centre, University of Jyväskylä, Jyväskylä, Finland

${ }^{\text {g} D e p a r t m e n t ~ o f ~ E x p e r i m e n t a l ~ P h y s i o l o g y, ~ M e d i c a l ~ S c h o o l, ~ N a t i o n a l ~ a n d ~ K a p o d i s t r i a n ~ U n i v e r s i t y ~}$ of Athens, Greece

Running title: MGF responses to resistance training

*Corresponding author:

\author{
Juha Ahtiainen, $\mathrm{PhD}$ \\ Department of Biology of Physical Activity \\ University of Jyväskylä \\ P.O. Box 35 \\ FIN-40014 University of Jyväskylä \\ Finland \\ Email: juha.ahtiainen@jyu.fi \\ Telephone: (358) 04-8053740
}




\begin{abstract}
IGF-I and its splice variants IGF-IEa and mechano growth factor (MGF) may play important role in muscular adaptations to resistance training (RT) that may be modulated by aging. It has been suggested that IGF-I induces cellular responses via Akt and ERK signaling pathways. Therefore, resistance exercise-induced changes in skeletal muscle IGF-IEa and MGF mRNA, and MGF, Erk1/2, Akt and p70S6K protein expression were investigated before and after 21-week of RT in younger (YM, 20-34 yrs., n=7) and older men (OM, 51-71 yrs., n=10). Experimental resistance exercises (RE; 5x10 repetition maximum leg presses) were performed pre- and post-RT. Muscle biopsies were obtained before and $48 \mathrm{~h}$ after REs, to study the late response to muscle loading. The muscle proteins or mRNAs of interest were not systematically influenced by the REs or RT, except for MGF mRNA expression which was increased $(p<0.01)$ following RE before RT in OM. No differences were observed between YM and OM in any variables. This study demonstrated that basal levels or RE-induced responses in skeletal muscle MGF, Erk1/2, Akt and p70S6K protein levels or IGF-IEa and MGF mRNA expression did not differ between YM and OM, nor change systematically due to RT. Thus, aging appears not to effect expression of the present signaling molecules involved in skeletal muscle hypertrophy.
\end{abstract}

Key words: mechano growth factor, muscle hypertrophy, gene expression, cell signaling, aging 


\section{ABBREVIATIONS}

IGF-I, Insulin-like growth factor-I

IGF-IEa, Insulin-like growth factor-I isoform Ea

MGF, Mechano growth factor

PI3K, Phosphoinositide 3-kinase

Akt, AKT8 virus oncogene cellular homolog

mTOR, Mechanistic target of rapamycin

p70S6K, p70 ribosomal S6 kinase

MAPK, Mitogen-activated protein kinases

Erk, Extracellular signal-regulated kinase

$\mathrm{RT}$, resistance training

$\mathrm{RE}$, resistance exercise

$\mathrm{RM}$, repetition maximum

YM, younger men

OM, older men

mRNA, messenger ribonucleic acid

GAPDH, Glyceraldehyde 3-phosphate dehydrogenase 


\section{INTRODUCTION}

Local growth factors expressed by the loaded muscle tissue, such as IGF-I splice variants IGF-IEa and Mechano Growth Factor (MGF/IGF-IEc) are part of a signaling network regulating exerciseinduced remodelling processes of skeletal muscle (Barton, 2006; Goldspink, 2005; Kandalla, Goldspink, Butler-Browne, \& Mouly, 2011). The cellular functions of IGF-I are mediated through its binding to the IGF-I receptor, which activates PI3K/Akt/mTOR/p70S6K and MAPK/Erk signaling pathways (Coolican, Samuel, Ewton, McWade, \& Florini, 1997; Rommel et al., 2001) that both can contribute to muscle growth (Clemmons, 2009). However, previous studies suggest that MGF stimulates the cellular processes via an IGF-I/insulin receptor-independent mechanism through Erk1/2 pathway (Milingos et al., 2011; Philippou et al., 2009; Stavropoulou et al., 2009).

Changes in expression of IGF-I splice variants have been postulated to contribute to the age-related decline in skeletal muscle mass (Hameed, Orrell, Cobbold, Goldspink, \& Harridge, 2003). In young adults, no net change occurs under the equilibrium conditions in skeletal muscle mass due to the balanced protein synthesis and degradation. However, during aging muscle tissue is gradually lost, resulting in diminished muscle mass and strength. IGF-I expression has been shown to be attenuated in older men (Welle, Bhatt, Shah, \& Thornton, 2002) suggesting that RT-induced adaptations in skeletal muscle IGF-I splice variants may also differ between young adult and older men.

Previously, we have investigated androgen receptor (Ahtiainen, Hulmi et al., 2011; Hulmi et al., 2008) and myostatin (Hulmi et al., 2007) responses to RT in the present subjects. We have also 
studied MGF and IGF-IEa mRNA responses to RE at post-RT in older men (Hulmi et al., 2008). This study is, however, first to examine skeletal muscle MGF protein levels following a long-term resistance training intervention. Furthermore, several other important questions not yet investigated will be addressed in the present study; 1) are RE-induced responses of IGF-1Ea and MGF mRNAs changed following long term RT, 2) are potential mediators of MGF function (Akt, Erk1/2, p70S6K) responsive to RE or RT and 3) are age differences observed in the present data. Thus, in this study we utilized previous data and muscle samples available for further analyses, focusing on the examination of the expression responses of IGF-I splice variants and their potential signaling proteins to RT in skeletal muscles. 


\section{MATERIALS AND METHODS}

\section{Subjects}

Healthy older men (OM, $\mathrm{n}=10,61 \pm 5$ years, height $177 \pm 3 \mathrm{~cm}$, body mass $80 \pm 5 \mathrm{~kg}$, body fat $\%$ $24 \pm 3$ ) and younger men (YM, n=7, $28 \pm 5$ years, height $185 \pm 3 \mathrm{~cm}$, body mass $79 \pm 6 \mathrm{~kg}$, body fat\% $17 \pm 4$ ) volunteers were recruited as described previously (Ahtiainen et al., 2011). Any subjects with a background in systematic physical training during the past 12 months before the study were excluded. The OM subjects were screened by a physician for their inclusion in this study. A medical screening included a resting electrocardiogram and a graded exercise test to volitional fatigue along with ECG monitoring under the supervision of a physician. Exclusion criteria included cardiovascular and pulmonary diseases, malfunctions of the thyroid gland, diabetes, body mass index $>28$, or any other disease that may have precluded the ability to perform the exercise training and testing. Exclusion criteria also included medications or nutritional supplements known to influence the cardiovascular and neuromuscular performance or endocrine system. The subjects who passed the baseline physical examination were accepted to the study. In accordance with the Declaration of Helsinki, all subjects were carefully informed about the possible risks and benefits of the study and all subjects signed a written consent before participation in the study. The ethics committees of the University of Jyväskylä and the Central Finland Health Care District approved the study.

\section{Experimental Design}

The subjects were carefully familiarized with all testing procedures prior to the study and had 
several warm-up contractions in all devices before actual measurements. The experimental variables were measured before and after RT for 21 weeks. To minimize the variability in the measures, the subjects were asked to refrain from any strenuous physical activity for at least three days before the measurements, and maintain a similar activity and dietary behavior pattern each time. Furthermore, all measurements were always performed at the same time of day to exclude the effects of diurnal variations.

\section{Resistance training program}

The present RT induced significant increases in muscle strength and size in both YM and OM, as reported previously (Ahtiainen et al., 2011). The RT program comprised resistance exercise sessions twice a week for 21 weeks. A minimum of two days of rest was required between the exercise sessions. RT consisted of both lower and upper body exercises with the goal to increase muscle mass and strength extensively throughout the training period. Leg press and knee extension and flexion exercises were performed for leg muscles. Four to five other exercises were performed for the other main muscle groups of the body (e.g. bench press, triceps pushdown, lateral pulldown, sit-up, elbow flexion). The number of sets of each exercise performed increased from 2-3 to 3-5 during the training period. RT consisted of three specific training periods, each lasting for 7 weeks: 1) to improve local muscular endurance after familiarizing to resistance exercises during the first training week. The training was carried out with light loads (40-60\% of 1 RM) but with multiple 10-20 RM per set and with short rest periods between the sets; 2) To produce muscle hypertrophy by increasing the loads progressively within $60-80 \%$ of the 1 RM (8-12 RM per sets) with a relatively short recovery time between the sets; 3) To optimize gains in maximal strength of trained muscles, while still increasing muscular hypertrophy. The training included also higher 
loads (up to $90 \%$ of the $1 \mathrm{RM}$ ) with longer recovery time between the sets using 5-8 RM loads. All training sessions were supervised by the research team, to make sure that proper technique and progression in the training loads were used in each exercise.

\section{Experimental Heavy Resistance Exercise}

To examine whether the changes in acute exercise-induced responses are connected to long-term RT condition, the experimental heavy resistance exercise (RE) sessions were performed before and after the 21-week RT period (Ahtiainen et al., 2011; Hulmi et al., 2007; Hulmi et al., 2008). After the training period, the RE was performed approximately one week after the last training session. The RE comprised of five sets of 10 RM sets of bilateral leg presses (David 210, David Fitness and Medical, Outokumpu, Finland) from a knee angle of $70^{\circ}$ to $180^{\circ}$ (= knee straight) with a two-minute recovery between the sets. The subjects were instructed not to consume any food or beverages for three hours prior to the REs.

Muscle Biopsy Procedure: Muscle biopsies were obtained as described previously (Ahtiainen et al., 2011; Hulmi et al., 2007; Hulmi et al., 2008). All the mRNA and protein analyses of each subject were performed simultaneously. To determine molecular responses during the regeneration phase after REs, muscle biopsies were obtained 30 minutes before and $48 \mathrm{~h}$ post-exercise to make the sample time coincide with the regenerative phase after the exercise (Ahtiainen, Lehti et al., 2011; Philippou et al., 2009). The subjects fasted for $3 \mathrm{~h}$ before obtaining the biopsies. Muscle samples were obtained from the middle portion of the vastus lateralis muscle by the use of the percutaneous needle biopsy technique. The surrounding area was cleaned with an antiseptic solution, and local anaesthetics ( $2 \mathrm{~mL}$ lidocaine-adrenalin, $1 \%)$ were administered subcutaneously 
prior to incision of the skin. A needle $(5 \mathrm{~mm})$ was inserted into the muscle belly and, with the aid of suction, approximately $100 \mathrm{mg}$ of muscle tissue was extracted. The muscle sample was cleaned of any visible connective and adipose tissue, as well as blood, and frozen within one minute in liquid nitrogen $\left(-180^{\circ} \mathrm{C}\right)$ for later analysis.

RNA analyses: Protocols for RNA analyses have been described previously (Hulmi et al., 2008). Muscle samples were homogenized with FastPrep (Bio101 Systems, USA) tissue homogenizer by using Lysing Matrix D (Q-Biogene, USA). Total RNA was extracted from 20-50 mg of muscle tissue using the Trizol-reagent (Invitrogen, Carlsbad, CA, USA) according to the manufacturer's instructions. The RNA concentration was determined photometrically at $260 \mathrm{~nm}$ using an optical density $\left(\mathrm{OD}_{260}\right)$ unit equivalent to $40 \mu \mathrm{g} / \mathrm{ml}$. The muscle sample RNA content was calculated on the basis of total RNA yield and the weight of the analyzed sample. The data (not shown) revealed that total RNA concentration of the samples did not change during the present study. The concentration and purity of RNA were determined by spectrophotometry at wavelengths of 260 and $280 \mathrm{~nm}$; OD260/OD280 ratio was $1.95 \pm 0.14$. The integrity of RNA was tested by agarose gel electrophoresis. Three micrograms of total RNA were reverse transcribed to synthesize cDNA, according to the manufacturer's instructions, in a total volume of $50 \mu 1$ using High Capacity cDNA Archive Kit (Part Number 4322171, Applied Biosystems, Foster City, CA, USA).

The mRNA expression of IGF-IEa and MGF and glyceraldehyde 3-phosphate dehydrogenase (GADPH) was determined using ABI 7300 Real-Time quantitative PCR System (Applied Biosystems, Foster City, CA, USA). PCR for IGF-IEa and MGF was performed with SYBR green mix (Cat. no. 204143, QuantiTect, Qiagen, Crawley, UK). The primers used for real time PCR were designed and analysed by Oligo Explorer and Analyzer software (Kuopio University, Finland) 
and synthesised by Oligomer Ltd. (Helsinki, Finland). The sequences $\left(5^{\prime}-3^{\prime}\right)$ of the primers for IGF-IEa gene were: IGF-IEa forward ATCTAAGGAGGCTGGAGATGTATTGC and IGF-IEa reverse TCAAATGTACTTCCTTCTGGGTCTTG, with product size of 114 bp. Each PCR reactions included; $12.5 \mu \mathrm{l}$ of SYBR Green master mix, $1.5 \mu \mathrm{l}$ of both gene specific primers (100 $\mu \mathrm{M}$, diluted 1:19 to $\mathrm{dH}_{2} \mathrm{O}$ ), $8.5 \mu \mathrm{l}$ of $\mathrm{dH}_{2} \mathrm{O}$, and $1 \mu \mathrm{l}$ of template cDNA (diluted 1:3 to $\mathrm{dH}_{2} \mathrm{O}$ ). False-positive results were controlled using negative (no-template) control samples that contained $\mathrm{dH}_{2} \mathrm{O}$ in place of template cDNA. PCR cycle parameters were: $50^{\circ} \mathrm{C}$ for 2 min and $95^{\circ} \mathrm{C}$ for 15 min, and 40 cycles of $94^{\circ} \mathrm{C}$ for $15 \mathrm{~s}$ (denaturation), $56^{\circ} \mathrm{C}$ for $30 \mathrm{~s}$ (annealing), $72^{\circ} \mathrm{C}$ for $30 \mathrm{~s}$ (extension) and $81^{\circ} \mathrm{C}$ for $15 \mathrm{~s}$ (data acquisition). The sequences $\left(5^{\prime}-3^{\prime}\right)$ of the primers for MGF gene were: MGF forward CGAA-GTCTCAGAGAAGGAAAGG and MGF reverse ACAGGTAACTCGTGCAGAGC, with product size of 150 bp (Hameed et al., 2003). PCR cycle parameters were: $50^{\circ} \mathrm{C}$ for $2 \mathrm{~min}$ and $95^{\circ} \mathrm{C}$ for $15 \mathrm{~min}$, and 40 cycles of $94^{\circ} \mathrm{C}$ for $15 \mathrm{~s}, 55^{\circ} \mathrm{C}$ for $30 \mathrm{~s}, 72^{\circ} \mathrm{C}$ for $30 \mathrm{~s}$ and $77^{\circ} \mathrm{C}$ for $15 \mathrm{~s}$. The specificity of the amplified target sequence was confirmed on observing a single reaction product of correct size on an agarose gel and a single peak on the DNA melting temperature curve determined at the end of the reaction. Each sample was analyzed in triplicate and the mean values were subsequently used for the analysis. The amount of specific mRNA in the sample was measured according to the corresponding genespecific standard curve created by serial dilutions of pooled samples. The mean amplification efficiency $\left(E=\left(10^{-1 / s l o p e}\right)-1\right)$ of the PCR reaction for IGF-IEa and MGF were 0.98 and 1.05, respectively. The mRNAs of IGF-IEa and MGF were normalized to a housekeeping gene, GADPH, which served as an endogenous control to correct for potential variation in RNA loading. GAPDH expression was not affected acutely or chronically by RT in the present samples (data not shown). The primer and probe for GAPDH was predesigned and validated by Applied Biosystems. The 
gene bank accession number and Applied Biosystems assay ID for GAPDH were NM002046 and Hs99999905_m1, respectively. The intra-assay coefficients of variations (CV) were 7.4\%, 11.0\% and $8.0 \%$ for IGF-IEa, MGF and GADPH, respectively. In our preliminary experiments the threshold cycle $(\mathrm{Ct})$ values were used to calculate the inter-assay CVs. Two separate runs on triplicate samples were performed for IGF-IEa $(n=16)$, MGF $(n=16)$ and GADPH $(n=19)$ with CVs of $2.3 \%, 2.7 \%$ and $5.6 \%$, respectively.

Western blot analysis: These methods have been published in detail elsewhere (Ahtiainen et al., 2011; Hulmi et al., 2008). Younger men's p70S6K and Akt expression have been published also partly previously (Hulmi et al., 2009), but all the samples were reanalyzed for the present study. Only total protein levels were analyzed in the present study since abundance of signal transmission enzymes are in high importance to physically interact with other signaling proteins and, thus, have an influence on capacity to regulate cellular processes. Moreover, later responses at $48 \mathrm{~h}$ after REs were studied, when also RE independent factors may have had effects on the activation levels of the present signaling proteins. Muscle biopsy specimens were homogenized on ice in a $4 \%(\mathrm{w} / \mathrm{v})$ solution in Mueller buffer (50 mM Hepes pH 7.4, 0.1\% Triton X-100, 4 mM EGTA, 10 mM EDTA, $15 \mathrm{mM}$ Na4P2O7·10H2O, $100 \mathrm{mM} \beta$-glycerolphosphate, $25 \mathrm{mM} \mathrm{NaF}, 1 \mathrm{mM} \mathrm{Na} 3 \mathrm{VO} 4,0.5 \mu \mathrm{g} / \mathrm{ml}$ leupeptin, $0.5 \mu \mathrm{g} / \mathrm{ml}$ pepstatin, and $0.3 \mu \mathrm{g} / \mathrm{ml}$ aprotinin). The homogenate was centrifuged for 15 $\min$ at $10000 \times \mathrm{g}$ at $4^{\circ} \mathrm{C}$. The protein concentration of the supernatant was determined using the Lowry based method (Bio-Rad, Hercules, CA). Each standard (BSA) and unknown was analyzed for protein concentration by using five replicates to increase reliability of the protein quantification. Aliquots of muscle lysate, containing $30 \mu \mathrm{g}$ of total protein, were solubilized in Laemmli sample buffer and heated at $95^{\circ} \mathrm{C}$ for $10 \mathrm{~min}$ to denature proteins, and were then separated by SDS-PAGE 
for $90 \mathrm{~min}$ at $200 \mathrm{~V}$ using 4-20\% gradient gels on Criterion electrophoresis cell (Bio-Rad Laboratories, Richmond, CA). All samples from each subject were run on the same 18-sample gel. In addition to that, the pre-training samples were analyzed with a separate run to compare the differences between the groups. Proteins were transferred to PVDF membranes at $350 \mathrm{~mA}$ constant current for $3 \mathrm{~h}$ on ice at $4^{\circ} \mathrm{C}$. The uniformity of protein loading was confirmed by staining the membrane with Ponceau S. Membranes were blocked in TBS with 0.1\% Tween 20 (TBS-T) containing $5 \%$ nonfat dry milk for $1 \mathrm{~h}$ and then incubated overnight at $4{ }^{\circ} \mathrm{C}$ with rabbit polyclonal primary antibodies. Antibodies recognizing Akt, Erk1/2(p44/p42), and p70S6K were purchased from Cell Signaling Technology (Beverly, MA) and MGF antibody was a gift from Dr. Koutsilieris Lab (Philippou et al., 2008). Peak phosphorylation of these signaling proteins typically occurs acutely within few hours following exercise loading and generally returns to basal levels within 24 hours. Present samples were collected $48 \mathrm{~h}$ post-exercise and, therefore, only total protein levels were studied to examine potential capacity of signaling pathways. All the primary antibodies were diluted at 1:2000 in TBS-T containing 2.5\% non-fat dry milk. Membranes were then washed $(5 \times$ $5 \mathrm{~min}$ ) in TBS-T, incubated with secondary antibody (horseradish peroxidase-conjugated antirabbit IgG; Cell Signaling Technology, USA) diluted at 1:25000 in TBS-T with $2.5 \%$ milk for $1 \mathrm{~h}$ followed by washing in TBS-T $(5 \times 5 \mathrm{~min})$. Proteins were visualized by ECL according to the manufacturer's protocol (SuperSignal west femto maximum sensitivity substrate, Pierce Biotechnology, Rockford, USA) and quantified (band intensity $\times$ volume) using a ChemiDoc XRS in combination with Quantity One software (version 4.6.3. Bio-Rad Laboratories, USA), and all measurements were normalized with the band of endogenous control sample (pooled sample loaded to each gel) and to the $36-\mathrm{kDa}$ GAPDH that served as a housekeeping protein (G9545, Sigma-Aldrich, St. Louis, MO, USA). 


\section{Statistics}

All the previously published data was reanalyzed for the present study. Standard statistical methods were used for the calculation of means and standard deviations (SD). The Shapiro-Wilk test was used to confirm normal distribution of the variables. Paired-Samples T-Test was used to analyze changes over time from pre-exercise or pre-training values. The differences between the groups were analyzed by the Independent-samples T-Test. The relationships between the variables were studied with the Pearson`s product moment correlation test. The level of significance was set at $\mathrm{p} \leq 0.05$. 


\section{RESULTS}

\section{IGF-I splice variants mRNA expression}

The expression level of IGF-I splice variants, namely IGF-IEa and MGF, were measured. IGF-IEa expression did not change due to RE, either before or after the 21-week RT period (Fig. 1). MGF expression increased in OM group due to RE only before the 21-week RT period, but not after it. No change was observed in the YM group. No change in the expression of IGF-IEa or MGF due to RT was observed in either of the age groups.

Insert figure 1 here

\section{Association of MGF protein to signalling proteins p70S6K, Erk1/2 and Akt}

Despite of the mRNA-level findings on MGF expression, RE performed before or after the 21week RT period did not change the protein expression of MGF in either of the age groups. RT also did not influence the abundancy of MGF at the protein level (Fig. 2). Neither group nor time differences were observed for p70S6K, Erk1/2 or Akt. Interestingly, significant correlations were revealed between the protein MGF and Erk1/2 pre- to post-RE changes, both before $(r=0.779, p$ $<0.001)$ and after RT $(r=0.864, \mathrm{p}<0.001)$ when the YM and OM group were combined. 


\section{DISCUSSION}

In the present study basal levels of RE-induced responses in skeletal muscle IGF-IEa and MGF mRNA expression, and of MGF, Erk1/2, Akt and p70S6K protein expression did not change systematically due to RT. Moreover, no statistically significant differences were observed between $\mathrm{YM}$ and $\mathrm{OM}$ group indicating that aging does not have an effect on these regulators of skeletal muscle size.

Autocrine and/or paracrine production of IGF-I and its splice variants is thought to be an important mediator of skeletal muscle adaptation to physical training (Haddad \& Adams, 2002; Hill \& Goldspink, 2003). In previous human studies investigating IGF-I splice variants, MGF mRNA response to acute resistance exercise bout (Hameed et al., 2003; Kim, Kosek, Petrella, Cross, \& Bamman, 2005; Petrella, Kim, Cross, Kosek, \& Bamman, 2006) and long-term resistance training (Petrella et al., 2006) have been observed to be greater in younger compared to older subjects, while no age differences have been observed in the IGF-IEa mRNA expression (Hameed et al., 2003; Petrella et al., 2006; Roberts et al., 2010). In the present study, however, increased MGF mRNA expression, due to RE, was observed before RT only in older men. IGF-I splice variants, IGF-IEa and MGF, may act as separate growth factors, and their expression may be differentially regulated. In particular, the expression of MGF has been demonstrated to be related to the mechanical strain of the muscle tissue (McKoy et al., 1999; Yang, Alnaqeeb, Simpson, \& Goldspink, 1996). Aging muscle has been shown to be especially susceptible to exercise-induced damage (Close, Kayani, Vasilaki, \& McArdle, 2005). The present RE protocol included concentric and eccentric muscle actions, which could have induced mechanical strain to contractile elements of skeletal muscle tissue predisposing activated muscle cells to damaging actions. Although 
muscle damage markers were not determined in the present study, it could be speculated that the present increases in MGF mRNA expression at 48 hours post-RE in OM were related to an extensive mechanical strain applied to muscle tissue of the previously untrained older individuals and, consequently, may be associated with muscle cell disruption and subsequent regenerative processes in the loaded muscles. Following the 21 -week RT, this response appears to be diminished. Regardless of the increases in the MGF mRNA expression, no changes were observed in MGF protein expression in this study. Previously, significant increases have been observed in MGF protein expression at 48h after eccentric loading (Philippou et al., 2009), while exercised muscles are still recovering of heavy resistance exercise (Ahtiainen et al., 2011). It could be suggested that the dynamic loading protocol used in the current study induced lower strain to exercised muscles when compared to the eccentric loading and, therefore, MGF protein expression did not increase at $48 \mathrm{~h}$ time point following the RE protocol used in the present study. However, it cannot be ruled out that the peak RE-induced responses were not observed within the biopsy schedule of this study.

Resistance exercise-induced muscular adaptations may be associated with changes in the expression of key proteins involved in the regulation of hypertrophic processes in trained skeletal muscles. IGF-I may be an important mediator of skeletal muscle growth acting through the PI3K/Akt/mTOR/p70S6K pathway (Alessi et al., 1996; Bodine et al., 2001) and MAPK signaling cascade, particularly via the Erk1/2 pathway (Haddad \& Adams, 2002). IGF-I can activate both of these pathways, while its splice variant MGF may primarily function via Erk1/2 signaling (Matheny, Nindl, \& Adamo, 2010) that can activate mTOR pathway independently of PI3K/Akt (Miyazaki, McCarthy, Fedele, \& Esser, 2011). In the present study, no statistically significant 
changes were observed over time in RE-induced responses of the signaling proteins Erk1/2, Akt and p70S6K, or in their baseline levels (before REs). Associations observed between RE-induced changes in MGF and Erk1/2 protein expression levels suggest that they may be, to some extent, linked between each other in cell signaling pathways (Philippou et al., 2009). In addition to the present analyses, we also correlated the present data with previously published results of RTinduced changes in muscle strength and size of the present subjects (Ahtiainen et al., 2011). Interestingly, the greatest increases in m.vastus lateralis fiber CSA were observed in those subjects whose pre-RT levels of $\mathrm{p} 70 \mathrm{~S} 6 \mathrm{~K}$ were largest $(\mathrm{r}=0.51, \mathrm{p}<0.05)$. Moreover, the RT-induced increase in leg muscle strength (determined by work performed during the REs) was also positively associated with pre-RT levels of p70S6K ( $\mathrm{r}=0.71, \mathrm{p}<0.001)$. Association between $\mathrm{p} 70 \mathrm{~S} 6 \mathrm{~K}$ and muscle hypertrophy has been observed also previously (Mayhew, Hornberger, Lincoln, \& Bamman, 2011; Mitchell et al., 2013). However, it should be noted that the causal effects of alterations in signaling protein expression on muscular adaptations to RT still remain unclear and requires further investigations.

In conclusion, the present findings showed that the heavy resistance exercise enhanced the expression of MGF at $48 \mathrm{~h}$ post-exercise especially in the older untrained men. The novel aspect of the present study was to examine skeletal muscle MGF protein levels in men of different ages. The data revealed that the REs or RT used in this study did not have an effect on MGF protein expression. The IGF-IEa or MGF mRNA expression or the levels of their potential signaling proteins (Erk1/2, Akt, p70S6K) did not change systematically due to the long-term RT (21 weeks). Notably, no differences were observed in any variable examined between the younger and older men either before or after the RT. 


\section{Conflict of interest statement}

None declared.

\section{Acknowledgements:}

The authors thank Mr. Risto Puurtinen and Mrs. Aila Ollikainen for their help in data collection and analysis. We also thank Dr. Koutsilieris Lab (Department of Experimental Physiology, Medical School, National and Kapodistrian University of Athens, Greece) for providing the MGF (IGF-IEc) antibody and the very dedicated group of subjects and research assistants who made this project possible. The Finnish Ministry of Education supported this research. 


\section{References}

Ahtiainen, J. P., Hulmi, J. J., Kraemer, W. J., Lehti, M., Nyman, K., Selanne, H., . . Hakkinen, K. (2011). Heavy resistance exercise training and skeletal muscle androgen receptor expression in younger and older men. Steroids, 76(1-2), 183-192. doi:10.1016/j.steroids.2010.10.012 [doi]

Ahtiainen, J. P., Lehti, M., Hulmi, J. J., Kraemer, W. J., Alen, M., Nyman, K., . . Hakkinen, K. (2011). Recovery after heavy resistance exercise and skeletal muscle androgen receptor and insulin-like growth factor-I isoform expression in strength trained men. Journal of Strength and Conditioning Research / National Strength \& Conditioning Association, 25(3), 767 777. doi:10.1519/JSC.0b013e318202e449; 10.1519/JSC.0b013e318202e449

Alessi, D. R., Andjelkovic, M., Caudwell, B., Cron, P., Morrice, N., Cohen, P., \& Hemmings, B. A. (1996). Mechanism of activation of protein kinase B by insulin and IGF-1. The EMBO Journal, 15(23), 6541-6551.

Barton, E. R. (2006). Viral expression of insulin-like growth factor-I isoforms promotes different responses in skeletal muscle. Journal of Applied Physiology (Bethesda, Md.: 1985), 100(6), 1778-1784. doi:01405.2005 [pii]

Bodine, S. C., Stitt, T. N., Gonzalez, M., Kline, W. O., Stover, G. L., Bauerlein, R., . . . Yancopoulos, G. D. (2001). Akt/mTOR pathway is a crucial regulator of skeletal muscle hypertrophy and can prevent muscle atrophy in vivo. Nature Cell Biology, 3(11), 10141019. doi:10.1038/ncb1101-1014 
Clemmons, D. R. (2009). Role of IGF-I in skeletal muscle mass maintenance. Trends in Endocrinology and Metabolism: TEM, 20(7), 349-356. doi:10.1016/j.tem.2009.04.002 [doi]

Close, G. L., Kayani, A., Vasilaki, A., \& McArdle, A. (2005). Skeletal muscle damage with exercise and aging. Sports Medicine (Auckland, N.Z.), 35(5), 413-427.

Coolican, S. A., Samuel, D. S., Ewton, D. Z., McWade, F. J., \& Florini, J. R. (1997). The mitogenic and myogenic actions of insulin-like growth factors utilize distinct signaling pathways. The Journal of Biological Chemistry, 272(10), 6653-6662.

Goldspink, G. (2005). Mechanical signals, IGF-I gene splicing, and muscle adaptation. Physiology (Bethesda, Md.), 20, 232-238. doi:10.1152/physiol.00004.2005

Haddad, F., \& Adams, G. R. (2002). Selected contribution: Acute cellular and molecular responses to resistance exercise. Journal of Applied Physiology (Bethesda, Md.: 1985), 93(1), 394-403. doi:10.1152/japplphysiol.01153.2001

Hameed, M., Orrell, R. W., Cobbold, M., Goldspink, G., \& Harridge, S. D. (2003). Expression of IGF-I splice variants in young and old human skeletal muscle after high resistance exercise. The Journal of Physiology, 547(Pt 1), 247-254. doi:10.1113/jphysiol.2002.032136

Hill, M., \& Goldspink, G. (2003). Expression and splicing of the insulin-like growth factor gene in rodent muscle is associated with muscle satellite (stem) cell activation following local tissue damage. The Journal of Physiology, 549(Pt 2), 409-418.

doi:10.1113/jphysiol.2002.035832 
Hulmi, J. J., Ahtiainen, J. P., Kaasalainen, T., Pollanen, E., Hakkinen, K., Alen, M., . . Mero, A. A. (2007). Postexercise myostatin and activin IIb mRNA levels: Effects of strength training. Medicine and Science in Sports and Exercise, 39(2), 289-297. doi:10.1249/01.mss.0000241650.15006.6e [doi]

Hulmi, J. J., Ahtiainen, J. P., Selanne, H., Volek, J. S., Hakkinen, K., Kovanen, V., \& Mero, A. A. (2008). Androgen receptors and testosterone in men--effects of protein ingestion, resistance exercise and fiber type. The Journal of Steroid Biochemistry and Molecular Biology, 110(1-2), 130-137. doi:10.1016/j.jsbmb.2008.03.030; 10.1016/j.jsbmb.2008.03.030

Hulmi, J. J., Tannerstedt, J., Selanne, H., Kainulainen, H., Kovanen, V., \& Mero, A. A. (2009). Resistance exercise with whey protein ingestion affects mTOR signaling pathway and myostatin in men. Journal of Applied Physiology (Bethesda, Md.: 1985), 106(5), 17201729. doi:10.1152/japplphysiol.00087.2009 [doi]

Kandalla, P. K., Goldspink, G., Butler-Browne, G., \& Mouly, V. (2011). Mechano growth factor E peptide (MGF-E), derived from an isoform of IGF-1, activates human muscle progenitor cells and induces an increase in their fusion potential at different ages. Mechanisms of Ageing and Development, 132(4), 154-162. doi:10.1016/j.mad.2011.02.007; 10.1016/j.mad.2011.02.007

Kim, J. S., Kosek, D. J., Petrella, J. K., Cross, J. M., \& Bamman, M. M. (2005). Resting and load-induced levels of myogenic gene transcripts differ between older adults with demonstrable sarcopenia and young men and women. Journal of Applied Physiology (Bethesda, Md.: 1985), 99(6), 2149-2158. doi:10.1152/japplphysiol.00513.2005 
Matheny, R. W.,Jr, Nindl, B. C., \& Adamo, M. L. (2010). Minireview: Mechano-growth factor: A putative product of IGF-I gene expression involved in tissue repair and regeneration. Endocrinology, 151(3), 865-875. doi:10.1210/en.2009-1217; 10.1210/en.2009-1217

Mayhew, D. L., Hornberger, T. A., Lincoln, H. C., \& Bamman, M. M. (2011). Eukaryotic initiation factor 2B epsilon induces cap-dependent translation and skeletal muscle hypertrophy. The Journal of Physiology, 589(Pt 12), 3023-3037. doi:10.1113/jphysiol.2010.202432 [doi]

McKoy, G., Ashley, W., Mander, J., Yang, S. Y., Williams, N., Russell, B., \& Goldspink, G. (1999). Expression of insulin growth factor-1 splice variants and structural genes in rabbit skeletal muscle induced by stretch and stimulation. The Journal of Physiology, 516 ( Pt 2)(Pt 2), 583-592.

Milingos, D. S., Philippou, A., Armakolas, A., Papageorgiou, E., Sourla, A., Protopapas, A., . . Koutsilieris, M. (2011). Insulinlike growth factor-1Ec (MGF) expression in eutopic and ectopic endometrium: Characterization of the MGF E-peptide actions in vitro. Molecular Medicine (Cambridge, Mass.), 17(1-2), 21-28. doi:10.2119/molmed.2010.00043; 10.2119/molmed.2010.00043

Mitchell, C. J., Churchward-Venne, T. A., Bellamy, L., Parise, G., Baker, S. K., \& Phillips, S. M. (2013). Muscular and systemic correlates of resistance training-induced muscle hypertrophy. PloS One, 8(10), e78636. doi:10.1371/journal.pone.0078636 [doi]

Miyazaki, M., McCarthy, J. J., Fedele, M. J., \& Esser, K. A. (2011). Early activation of mTORC1 signalling in response to mechanical overload is independent of phosphoinositide 
3-kinase/akt signalling. The Journal of Physiology, 589(Pt 7), 1831-1846.

doi:10.1113/jphysiol.2011.205658; 10.1113/jphysiol.2011.205658

Petrella, J. K., Kim, J. S., Cross, J. M., Kosek, D. J., \& Bamman, M. M. (2006). Efficacy of myonuclear addition may explain differential myofiber growth among resistance-trained young and older men and women. American Journal of Physiology.Endocrinology and Metabolism, 291(5), E937-46. doi:00190.2006 [pii]

Philippou, A., Papageorgiou, E., Bogdanis, G., Halapas, A., Sourla, A., Maridaki, M., .. . Koutsilieris, M. (2009). Expression of IGF-1 isoforms after exercise-induced muscle damage in humans: Characterization of the MGF E peptide actions in vitro. In Vivo (Athens, Greece), 23(4), 567-575.

Philippou, A., Stavropoulou, A., Sourla, A., Pissimissis, N., Halapas, A., Maridaki, M., \& Koutsilieris, M. (2008). Characterization of a rabbit antihuman mechano growth factor (MGF) polyclonal antibody against the last 24 amino acids of the E domain. In Vivo (Athens, Greece), 22(1), 27-35.

Roberts, M. D., Dalbo, V. J., Sunderland, K. L., Poole, C. N., Hassell, S. E., Bemben, D., . . Kerksick, C. M. (2010). IGF-1 splice variant and IGF-1 peptide expression patterns in young and old human skeletal muscle prior to and following sequential exercise bouts. European Journal of Applied Physiology, 110(5), 961-969. doi:10.1007/s00421-010-1588$2 ; 10.1007 / \mathrm{s} 00421-010-1588-2$

Rommel, C., Bodine, S. C., Clarke, B. A., Rossman, R., Nunez, L., Stitt, T. N., . . Glass, D. J. (2001). Mediation of IGF-1-induced skeletal myotube hypertrophy by PI(3)K/akt/mTOR 
and PI(3)K/akt/GSK3 pathways. Nature Cell Biology, 3(11), 1009-1013. doi:10.1038/ncb1101-1009

Stavropoulou, A., Halapas, A., Sourla, A., Philippou, A., Papageorgiou, E., Papalois, A., \& Koutsilieris, M. (2009). IGF-1 expression in infarcted myocardium and MGF E peptide actions in rat cardiomyocytes in vitro. Molecular Medicine (Cambridge, Mass.), 15(5-6), 127-135. doi:10.2119/molmed.2009.00012; 10.2119/molmed.2009.00012

Welle, S., Bhatt, K., Shah, B., \& Thornton, C. (2002). Insulin-like growth factor-1 and myostatin mRNA expression in muscle: Comparison between 62-77 and 21-31 yr old men. Experimental Gerontology, 37(6), 833-839. doi:S0531556502000256 [pii]

Yang, S., Alnaqeeb, M., Simpson, H., \& Goldspink, G. (1996). Cloning and characterization of an IGF-1 isoform expressed in skeletal muscle subjected to stretch. Journal of Muscle Research and Cell Motility, 17(4), 487-495. 


\section{FIGURE LEGENDS}

Fig. 1. Fold changes (mean \pm SEM) of pre- to post $48 \mathrm{~h}$ experimental heavy resistance exercise (RE, 5 x 10RM leg presses) and pre-exercise (resting) values from pre to post 21-week resistance training period (RT) in ${ }^{\text {a) }}$ IGF-IEa and ${ }^{\text {b) }}$ MGF mRNA expression. The data of post-RT has been published previously in Hulmi et al. 2008. **: Statistically significant change $(\mathrm{p}<0.01)$ from the corresponding pre-exercise value.

Fig. 2. Changes (mean $\pm \mathrm{SD}$ ) in ${ }^{\text {a) }} \mathrm{MGF},{ }^{\mathrm{b})} \mathrm{p} 70 \mathrm{~S} 6 \mathrm{~K},{ }^{\mathrm{c})}$ Erk1/2, and ${ }^{\text {d) }}$ Akt protein expression due to the experimental heavy resistance exercise (RE, $5 \times 10 \mathrm{RM}$ leg presses) before and after the 21week experimental heavy resistance training period (RT). Representative images of Ponceu S staining and immunoblots of MGF, p70S6K1, Erk1/2, Akt, and GAPDH at pre- and post RE before and after RT are shown on the right side of the figure. 
Figure 1

A)

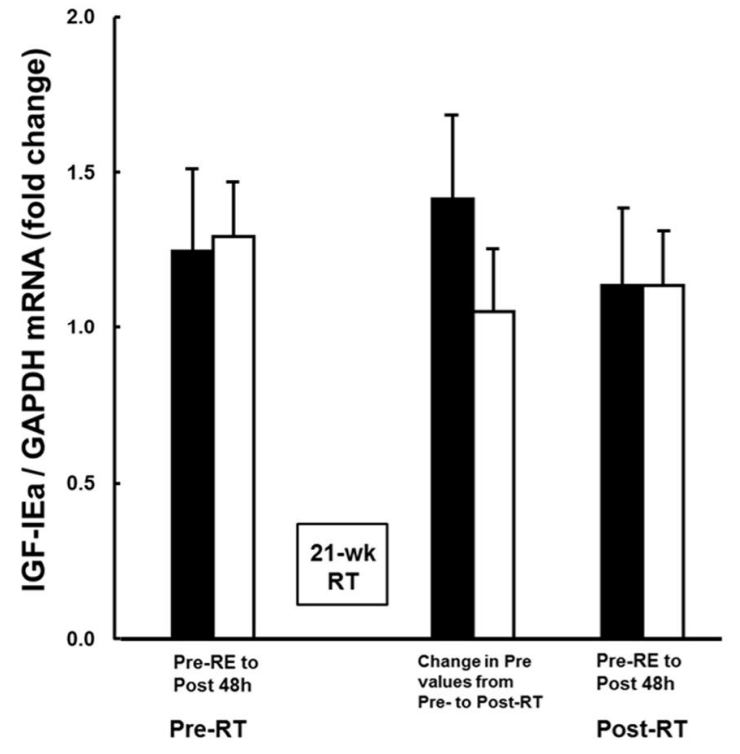

B)

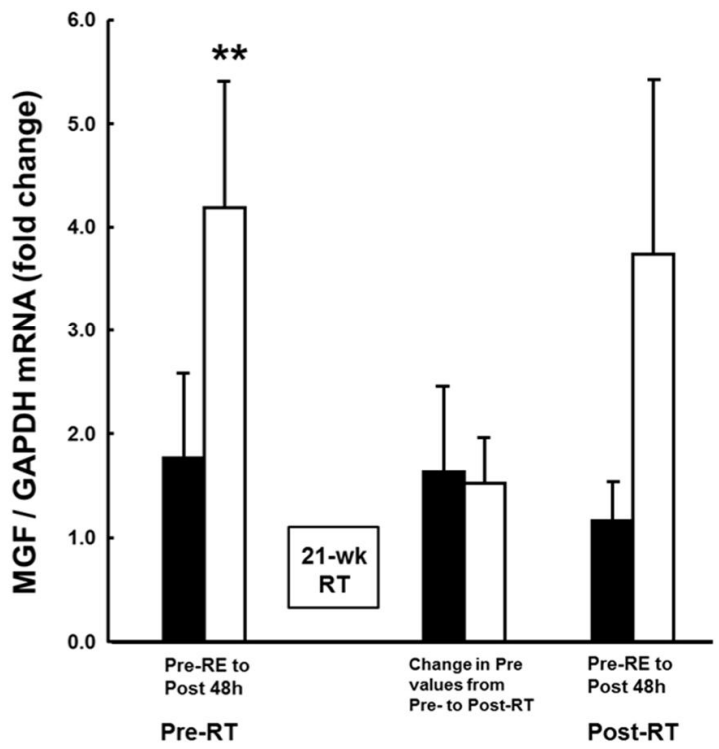


Figure 2

A)

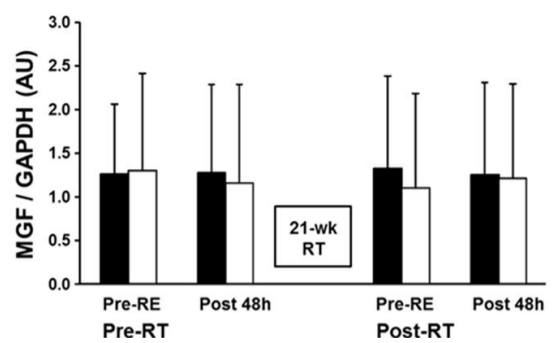

C)

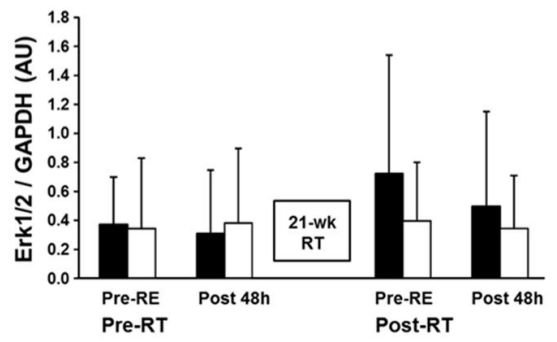

B)

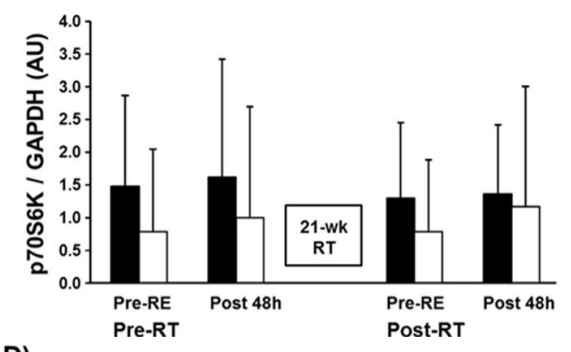

D)

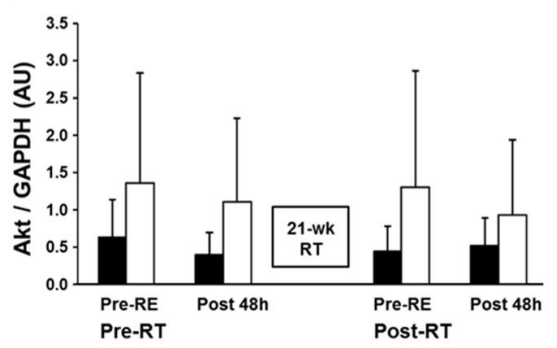

- Younger men

口Older men Pre-RE Post-RE Pre-RE Post-RE MGF p7056א1 Erk1/2 Akt GAPDH Ponceau S 